\title{
MODEL PENAWARAN DAN PERMINTAAN MINYAK KELAPA SAWIT INDONESIA DI PASAR INTERNASIONAL
}

\author{
Supply and Demand Model of Indonesian Palm Oil in the International Market
}

\author{
Tia Sofiani Napitupulu, Djaimi Bakce, Almasdi Syahza, Brilliant Asmit, Syaiful Hadi \\ Program Studi Magister Agribisnis Universitas Riau \\ Kampus Bina Widya No. 30 KM. 12,5 Simp. Baru Panam, Pekanbaru \\ Email: sofianitia@gmail.com
}

\begin{abstract}
Indonesia is the leading producer of palm oil in the world. In 2016 Indonesia and Malaysia produced $81 \%$ of the world's palm oil. This study aims to analyze the response of the supply and demand for Indonesian palm oil in the world market. This study used time-series data from 19802016. The model built is an econometric model, simultaneous equations. To answer the research objectives, the data were analyzed using the Two Stages Least Square (2SLS) method. The main finding of this study is that in the short term, there are no responsive variables. In the long term, the variable that is responsive to the supply of Indonesian palm oil is the lag area of Indonesian palm oil. In the Malaysian palm oil supply equation, the response variable is the lag area of Malaysian palm oil. In terms of domestic demand for Indonesian palm oil, there are no responsive variables both in the short and long term. In the equation of demand for Malaysian palm oil, the responsive variables are the price of Malaysian palm oil and the price of Malaysian coconut oil. In the international demand for palm oil, the responsive variables are the increase in world palm oil prices, world palm oil prices, 2-year lag in world palm oil prices, and GDP per capita Pakistan. In terms of price, the responsive variable affecting the price of Indonesian palm oil is the world price of palm oil.
\end{abstract}

Keywords: Palm Oil, Simultaneous Equation, Supply, Demand

\begin{abstract}
ABSTRAK
Indonesia merupakan produsen utama minyak kelapa sawit dunia. Pesaing utama Indonesia adalah Malaysia. Pada tahun 2016 Indonesia dan Malaysia memproduksi 81\% minyak kelapa sawit yang ada di dunia. Penelitian ini bertujuan untuk menganalisis besarnya respon penawaran dan permintaan minyak kelapa sawit Indonesia di pasar dunia. Penelitian ini menggunakan data times series tahun 1980-2016. Model yang dibangun merupakan model ekonometrik, persamaan simultan. Untuk menjawab tujuan penelitian, data dianalisis menggunakan metode Two Stages Least Square (2SLS). Temuan utama dari penelitian ini adalah bahwa dalam jangka pendek, tidak ada peubah yang bersifat responsif terhadap penawaran dan permitaan minyak kelapa sawit Indonesia. Dalam jangka panjang peubah yang bersifat responsif terhadap penawaran minyak kelapa sawit Indonesia adalah lag luas lahan kelapa sawit Indonesia. Pada persamaan penawaran minyak kelapa sawit Malaysia, peubah yang responsif adalah lag luas lahan kelapa sawit Malaysia. Dilihat dari sisi permintaan domestik minyak kelapa sawit Indonesia, tidak ada peubah yang responsif baik dalam jangka pendek maupun dalam jangka panjang. Pada persamaan permintaan minyak kelapa sawit Malaysia, peubah yang bersifat responsif adalah harga minyak kelapa sawit Malaysia dan harga minyak kelapa Malaysia. Pada permintaan minyak kelapa sawit internasional, peubah yang responsif adalah penambahan harga minyak kelapa sawit dunia, harga minyak kelapa sawit dunia, lag 2 tahun harga minyak kelapa sawit dunia, dan GDP Pakistan per kapita. Dari sisi harga, peubah yang responsif mempengaruhi harga minyak kelapa sawit Indonesia adalah harga minyak kelapa sawit dunia.
\end{abstract}

Kata Kunci: Minyak Kelapa Sawit, Persamaan Simultan, Penawaran, Permintaan 


\section{PENDAHULUAN}

Kelapa sawit merupakan salah satu komoditas strategis Indonesia, dilihat dari perannya yang besar terhadap pembangunan perekonomian Indonesia (BPDP, 2019; Sipayung dan Purba, 2015). Kegiatan produksi kelapa sawit dari hulu ke hilir merupakan kegiatan yang padat karya sehingga secara langsung berkontribusi besar terhadap penyerapan tenaga kerja. Pada tahun 2018 jumlah petani swadaya kelapa sawit tercatat sebanyak 2,6 juta, dengan mempekerjakan 4,3 juta pekerja buruh tani. Pada industri kelapa sawit tercatat pekerja yang terlibat langsung sebanyak 4,2 juta, sementara itu pekerja tak langsung tercatat sebanyak 12 juta. Selain itu kelapa sawit juga berperan terhadap peningkatan neraga perdagangan, menurunkan inflasi, mengurangi belanja pemerintah, dan meningkatkan real capital return (BPDP, 2019).

Kelapa sawit juga merupakan salah satu produk andalan ekspor Indonesia. Berdasarkan data yang dihimpun dari Bank Indonesia (2018) dinyatakan bahwa perbaikan ekspor Indonesia masih sangat bergantung pada ekspor berbasis komoditas. Komoditas pertanian merupakan penyumbang terbesar dalam ekspor non migas. Pada tahun 2017 tercatat ekspor rill komoditas pertanian sebesar 17 persen, nilai ini diperoleh atas dorongan kenaikan ekspor minyak kelapa sawit mentah (CPO) dan karet. Ekspor rill CPO telah tumbuh 8,2 persen, nilai ini lebih tinggi dibandingkan dengan pertumbuhan pada tahun 2016 yang tercatat sebesar 0,4 persen. Permintaan ekspor CPO salah satunya dipengaruhi oleh tingginya permintaan minyak kelapa sawit (Bank Indonesia, 2018).

Ditinjau dari sisi permintaan dan penawaran minyak kelapa sawit Indonesia, keduanya menunjukkan perkembangan yang positif seperti yang disajikan pada Gambar 1 . Perkembangan penawaran minyak kelapa sawit Indonesia lebih besar jika dibandingkan dengan permintaan minyak kelapa sawit Indonesia. Data yang dirilis oleh Sekjen Perkebunan Republik Indonesia menunjukkan bahwa pada tahun 2017 permintaan minyak kelapa sawit Indonesia mencapai 16,43 juta ton. Sementara itu jumlah penawaran minyak kelapa sawit Indonesia mencapai 45,56 juta ton.



Sumber: Sekretariat Direktorat Jenderal Perkebunan, 2018

Gambar 1. Perkembangan Penawaran dan Permintaan Minyak Kelapa Sawit (CPO) Indonesia Tahun 1981-2017

Indonesia merupakan produsen utama kelapa sawit dunia, sejak tahun 2006 telah menggeser posisi Malaysia sebagai produsen utama. Saat ini, kedua negara tersebut merupakan produsen utama minyak kelapa sawit dunia. Berdasarkan data yag dikumpulkan dari Food Agriculture Organisation (FAO) diketahui bahwa pada tahun 2017 produksi minyak kelapa sawit Indonesia dan Malaysia telah mencapai 82 persen dari total produksi minyak kelapa sawit yang ada di dunia (FAO, 2019). Dilihat dari perkembangan produksi kedua negara tersebut menunjukkan perkembangan yang positif seperti yang disajikan pada Gambar 2. Berdasarkan 
Gambar 2 diketahui bahwa pada tahun 2016 produksi minyak kelapa sawit Indonesia adalah sebesar 40,20 juta ton, produksi minyak kelapa sawit Malaysia adalah sebesar 29,76 juta ton, dan produksi minyak kelapa sawit sisa dunia adalah sebesar 14,49 juta ton.

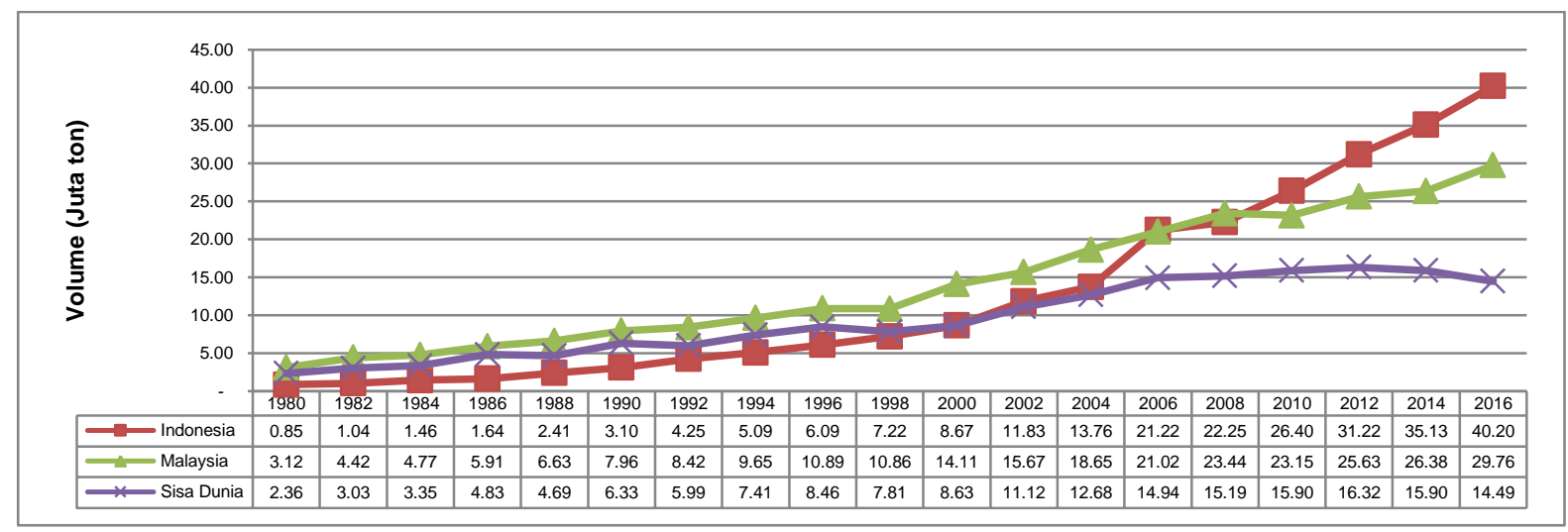

Sumber: FAO, 2019

Gambar 2. Perkembangan Produksi Minyak Kelapa Sawit Negara Produsen Minyak Kelapa Sawit Dunia Tahun 1980-2016

Kelapa sawit sebagai komoditas strategis yang mempunyai potensi besar untuk dikembangkan, seperti yang telah dipaparkan diatas pada kenyataannya tidak terlepas dari beragam permasalahan. Dimulai dari hulu hingga hilir, beberapa permasalahan tersebut diantaranya adalah produktivitas kelapa sawit yang rendah, harga minyak kelapa sawit yang fluktuatif, budidaya kelapa sawit yang belum sesuai dengan good practice, rendahnya kualitas produk kelapa sawit Indonesia, terbatasnya produk turunan kelapa sawit Indonesia, black campaign terhadap kelapa sawit Indonesia yang berujung pada penolakan terhadap produk kelapa sawit Indonesia.

Berdasarkan uraian diatas maka tujuan dari penelitian ini adalah untuk membangun model persamaan penawaran dan permintaan minyak kelapa sawit Indonesia. Penelitian ini juga bertujuan untuk melihat faktor apa saja yang mempengaruhi permintaan dan penawaran minyak kelapa sawit Indonesia, serta bagaimana responnya terhadap penawaran dan permintaan minyak kelapa sawit Indonesia.

\section{METODE PENELITIAN}

Penelitian ini dilaksanakan mulai bulan Januari hingga Oktober 2018. Data yang digunakan pada penelitian ini adalah data sekunder, yaitu data time series tahun 1980 sampai dengan tahun 2016. Adapun data yang digunakan pada penelitian ini adalah data luas lahan kelapa sawit Indonesia dan Malaysia, produksi kelapa sawit negara produsen, harga minyak kelapa sawit dan harga substitusi minyak kelapa sawit (minyak kedelai, minyak biji bunga matahari dan minyak kelapa), ekspor minyak kelapa sawit, impor minyak kelapa sawit, nilai tukar terhadap dolar, indeks harga konsumen, dan Produk Domestik Bruto (PDB). Pada penelitian ini data dikumpulkan dari berbagai sumber diantaranya BPS Indonesia, Bank Indonesia, FAO, dan Bank Dunia.

Dalam menganalisis data pada penelitian ini melalui beberapa tahapan, dimulai dari spesifikasi model, identifikasi model, dan perhitungan elastisitas.

\section{Spesifikasi Model}

Spesifikasi model adalah tahapan pertama dari analisis data pada penelitian ini. Spesifikasi model adalah kegiatan menggambarkan hubungan antara peubah-peubah yang dimasukkan kedalam model, peubah tersebut kemudian diformulasikan kedalam persamaan struktural dan persamaan identitas (Koutsoyiannis, 1977; dan Gujarati, 2011. Untuk memudahkan pembahasan maka spesifikasi model pada penelitian ini dikelompokkan kedalam tiga blok, yaitu blok penawaran, blok permintaan, dan blok harga. Blok penawaran minyak kelapa sawit terdiri dari 5 (lima) persamaan, diantaranya adalah persamaan penawaran minyak kelapa sawit Indonesia (SID), penawaran minyak kelapa sawit Malaysia (SMY), ekspor minyak kelapa sawit Indonesia (XIDPO), ekspor minyak kelapa sawit Malaysia (XMYPO), dan total ekspor minyak kelapa sawit Indonesia (TXWPO). Blok 
permintaan minyak kelapa sawit terdiri dari 6 (enam) persamaan yaitu persamaan permintaan minyak kelapa sawit Indonesia (DID), permintaan minyak kelapa sawit Malaysia (DMY), impor minyak kelapa sawit India (MINPO), impor minyak kelapa sawit China (MCHPO), impor minyak kelapa sawit Pakistan (MPAPO), dan total impor minyak kelapa sawit dunia (TMWPO). Blok harga minyak kelapa sawit terdiri dari 3 (tiga) persamaan yaitu persamaan harga minyak kelapa sawit Indonesia (PPOID), harga minyak kelapa sawit Malaysia (PPOMY), dan harga minyak kelapa sawit dunia (PPOW). Spesifikasi model penawaran dan permintaan minyak kelapa sawit Indonesia disajikan pada Gambar 3.



Gambar 3. Spesifikasi Model Penawaran dan Permintaan Minyak Kelapa Sawit Indonesia

\section{Identifikasi Model}

Identifikasi model pada setiap persamaan pada model persamaan simultan dengan menggunakan syarat order condition dengan rumus sebagai berikut (Gujarati, 2011; Pindyck and Rubinfield, 2000; Intriligator, 1978; Koutsoyiannis, 1977):

$$
(\mathrm{K}-\mathrm{M}) \geq \mathrm{G}-1
$$

dimana: $\mathrm{K}=$ Total peubah dalam model, yaitu peubah endogen dan peubah determinan; $\mathrm{M}=$ Jumlah peubah endogen dan eksogen yang dimasukkan ke dalam suatu persamaan tertentu dalam model; $\mathrm{G}=$ Total persamaan dalam model (jumlah peubah endogen)

Adapun kriteria dalam melakukan identifikasi model menggunakan ketentuan order condition yang dinyatakan sebagai berikut:
(1) Jika $(\mathrm{K}-\mathrm{M})=(\mathrm{G}-1)$, maka persamaan dalam model dinyatakan teridentifikasi secara tepat (exactly identified); (2) Jika (K-M) < (G-1), maka persamaan dalam model dinyatakan tidak teridentifikasi (unidentified); (3) Jika (K-M) > (G-1), maka persamaan dalam model dinyatakan teridentifikasi berlebih (overidentified).

Berdasarkan model yang dirumuskan pada model penawaran dan permintaan minyak kelapa sawit Indonesia terdiri dari 12 persamaan struktural dan 2 persamaan identitas, sehingga total persamaan adalah 14 persamaan $(\mathrm{G})$. Jumlah peubah endogen 14 dan peubah eksogen 24 , dengan total peubah dalam model (K) 38 . Jumlah peubah endogen dan eksogen terbanyak 
yang dimasukkan dalam suatu persamaan tertentu (M) adalah 4 peubah.

Dengan demikian, berdasarkan kriteria order condition setiap persamaan struktural dalam model penawaran dan permintaan minyak kelapa sawit Indonesia adalah overidentified sehingga metode yang digunakan adalah Two Stage Least Squares (2SLS). Pada penelitian ini batas toleransi yang ditetapkan untuk uji statistik $\mathrm{t}$ adalah 20 persen.

\section{Elastisitas}

Penghitungan nilai elastisitas digunakan untuk mendapatkan nilai kuantitatif dari respon suatu fungsi terhadap faktor-faktor yang mempengaruhinya. Perhitungan elastisitas juga digunakan untuk melihat peubah yang signifikan mempengaruhi model, dan bagaimana pengaruh peubah tersebut terhadap model. Perhitungan elastisitas dihitung dalam jangka pendek dan jangka panjang dengan menggunakan rumus sebagai berikut (Sukirno, 2014):

$$
\begin{aligned}
& \mathrm{E}_{\mathrm{SR}}=\frac{\partial \mathrm{Y}_{\mathrm{t}}}{\partial \mathrm{X}_{\mathrm{t}}} * \frac{\overline{\mathrm{X}}}{\mathrm{Y}}=\mathrm{b} \frac{\overline{\mathrm{X}}}{\overline{\mathrm{Y}}} \\
& E_{\mathrm{LR}}=\frac{\mathrm{E}_{\mathrm{SR}}}{1-\mathrm{b}_{\mathrm{lag}}} \text {. }
\end{aligned}
$$

dimana : ESR = Elastisitas jangka pendek; ELR $=$ Elastisitas jangka panjang; $\mathrm{b}=$

Parameter dugaan dari peubah eksogen; $\bar{X}=$ Rata-rata peubah eksogen; $\bar{Y}=$ Rata-rata peubah endogen.

\section{HASIL PEMBAHASAN}

Hasil pendugaan model penawaran dan permintaan minyak kelapa sawit Indonesia disajikan pada Tabel 1. Berdasarkan tabel 1 dapat dilihat bahwa secara umum hasil pendugaan model penawaran dan permintaan minyak kelapa sawit Indonesia cukup baik. Indikator penilaian yang digunakan adalah berdasarkan kriteria ekonomi, berdasarkan nilai koefisien determinasi, dan nilai F. Berdasarkan kriteria ekonomi dapat dinyatakan bahwa semua peubah yang telah dimasukkan ke dalam model persamaan telah memiliki tanda yang sesuai dengan yang diharapkan. Berdasarkan nilai koefisien determinasi $\left(\mathrm{R}^{2}\right)$, pada model ini berkisar antara 0,8450 sampai 0,9958. Koefisien determinasi menunjukkan sejauh apa model persamaan mampu menjelaskan keadaan aktualnya. Dilihat dari nilai koefisien determinasi dapat dikatakan bahwa model pada persamaan ini cukup baik, karena secara keseluruhan peubah-peubah eksogen telah mampu menjelaskan dengan baik peubah endogennya. Nilai koefisien determinasi persamaan penawaran minyak kelapa sawit Indonesia (SID) adalah sebesar 0,9958 dapat diartikan bahwa variasi peubah-peubah yang dimasukkan kedalam persamaan penawaran minyak kelapa sawit Indonesia telah mampu menjelaskan persamaan penawaran minyak kelapa sawit Indonesia sebesar 99,58 persen. Perhitungan nilai $\mathrm{F}$ memiliki besaran nilai antara 40,87 sampai 1.893,86. Hasil uji F menunjukkan bahwa seluruh persamaan dalam model berbeda nyata dengan nol pada taraf 1 (satu) persen.

Hasil pendugaan model penawaran dan permintaan minyak kelapa sawit Indonesia di pasar internasional disajikan pada Tabel 1. Pembahasan model persamaan dikelompokkan menjadi tiga blok, yaitu penawaran minyak kelapa sawit, permintaan minyak kelapa sawit, dan harga minyak kelapa sawit.

\section{Penawaran Minyak Kelapa Sawit}

Blok penawaran minyak kelapa sawit terdiri dari 4 (empat) persamaan yaitu penawaran minyak kelapa sawit Indonesia (SID), penawaran minyak kelapa sawit Malaysia (SMY), ekspor minyak kelapa sawit Indonesia (XIDPO), dan ekspor minyak kelapa sawit Malaysia (XMYPO). Secara umum peubahpeubah yang berpengaruh signifikan pada penawaran minyak kelapa sawit adalah lag luas lahan kelapa sawit Indonesia (LAHID), harga pupuk urea (PURIDR), lag luas lahan kelapa sawit Malaysia (LAHMY), nilai tukar Rupiah terhadap US Dolar (ERIDRR), dan penambahan permintaan minyak kelapa sawit Malaysia (ADMY). Dalam jangka pendek tidak ada peubah yang bersifat elastis, yang dilihat dari nilai elastisitas $\left(\mathrm{E}_{\mathrm{SR}}\right)$ yang lebih kecil dari satu. Sementara itu dalam jangka panjang peubah yang bersifat elastis adalah lag luas lahan kelapa sawit Indonesia (LAHID), lag luas lahan kelapa sawit Malaysia (LAHMY), dan nilai tukar Rupiah terhadap US Dolar (ERIDRR).

Penawaran minyak kelapa sawit Indonesia dipengaruhi oleh empat peubah yaitu penambahan harga minyak kelapa sawit Indonesia (APPOIDR), lag luas lahan kelapa sawit Indonesia (LAHID), harga pupuk urea (PURIDR) dan lag penawaran minyak kelapa sawit Indonesia tahun sebelumnya (LSID). Peubah yang berpengaruh signifikan terhadap penawaran minyak kelapa sawit Indonesia 
adalah lag luas lahan kelapa sawit Indonesia (LAHID) dan harga pupuk urea (PURIDR). Dalam jangka pendek, perubahan kedua peubah tersebut tidak memberikan pengaruh yang besar atau tidak responsif terhadap penawaran minyak kelapa sawit Indonesia. Hal ini dapat dilihat dari nilai elastisitas jangka pendek $\left(\mathrm{E}_{\mathrm{SR}}\right)$ yang lebih kecil dari satu. Nilai $\mathrm{E}_{\mathrm{SR}}$ pubah lag luas lahan kelapa sawit Indonesia (LAHID) adalah sebesar 0,5757 dapat diartikan bahwa apabila lag luas lahan kelapa sawit Indonesia (LAHID) meningkat sebesar 1 (satu) persen, maka penawaran minyak kelapa sawit Indonesia hanya akan meningkat sebesar 0,5757 persen. Dalam jangka panjang, peubah yang bersifat responsif terhadap penawaran minyak kelapa sawit Indonesia adalah peubah lag luas lahan kelapa sawit Indonesia (LAHID). Nilai elastisitas jangka panjang $\left(\mathrm{E}_{\mathrm{LR}}\right)$ peubah LAHID adalah 1,2055 dapat diinterpretasikan bahwa jika lag luas lahan kelapa sawit Indonesia $\left(\mathrm{E}_{\mathrm{LR}}\right)$ meningkat sebesar 10 persen, maka penawaran minyak kelapa sawit Indonesia akan meningkat sebesar 12,055 persen.

Tabel 1. Hasil Pendugaan Model Penawaran dan Permintaan Minyak Kelapa Sawit Indonesia di Pasar Internasional

\begin{tabular}{|c|c|c|c|c|c|c|}
\hline \multirow{2}{*}{ Nama Peubah } & \multirow{2}{*}{ Notasi } & \multirow{2}{*}{$\begin{array}{c}\text { Parameter } \\
\text { Dugaan }\end{array}$} & \multirow{2}{*}{ t hitung } & \multirow{2}{*}{$\operatorname{Pr}>|\mathbf{t}|$} & \multicolumn{2}{|c|}{ Elastisitas } \\
\hline & & & & & $\mathbf{E}_{\mathrm{SR}}$ & $\mathbf{E}_{\mathrm{LR}}$ \\
\hline \multicolumn{7}{|c|}{$\begin{array}{ll}\text { Penawaran minyak kelapa sawit Indonesia } & \text { SID }\end{array}$} \\
\hline Intercept & Intercept & 0.9375 & 1.9 & 0.0677 & - & \\
\hline Penambahan PPOIDR & APPOIDR & 0.0002 & 0.61 & 79 & - & \\
\hline Lag AHID & LAHID & 2.8315 & 3.29 & 026 & 0.5757 & 1.2055 \\
\hline Harga pupuk urea & PURIDR & -0.0003 & -1.45 & 0.1566 & -0.1217 & -0.2548 \\
\hline Lag SID & LSID & 0.5225 & 3.03 & 0.0050 & - & 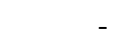 \\
\hline \multicolumn{7}{|c|}{$\mathrm{R} 2=0.9958 ; \mathrm{F}$ hitung $=1793.86 ; \mathrm{Pr}>\mathrm{F}=\langle .0001 ; \mathrm{dh}=-$} \\
\hline Penawaran minyak kelapa sawit Malaysia & SMY & & & & & \\
\hline Intercept & Intercept & -0.4002 & -0.47 & 0.6449 & - & \\
\hline Lag PPOMYR & LPPOMYR & 0.0005 & 0.62 & 0.5395 & - & \\
\hline Lag AHMY & LAHMY & 0.9628 & 1.59 & 0.1225 & 0.1958 & 1.3281 \\
\hline \multirow[t]{2}{*}{ Lag SMY } & LSMY & 0.8526 & 7.91 & $<.0001$ & - & \\
\hline & \multicolumn{6}{|c|}{$\mathrm{R} 2=0.9865 ; \mathrm{F}$ hitung $=757.42 ; \operatorname{Pr}>\mathrm{F}=<.0001 ; \mathrm{dh}=-2.42$} \\
\hline Ekspor minyak kelapa sawit Indonesia & XIDPO & & & & & \\
\hline Inter & Inter & 0.1277 & 0.32 & 09 & - & \\
\hline rar Rupiah & ERI & 0.0005 & 2.54 & 65 & 0.3033 & 1.1503 \\
\hline PPOWR & APP & -0.0011 & -1.08 & 896 & - &  \\
\hline $\mathrm{Lag}$ & LXIDPO & 0.7363 & 6.14 & 001 & - & \\
\hline \multicolumn{7}{|c|}{$\mathrm{R} 2=0.9671 ; \mathrm{F}$ hitung $=303.79 ; \mathrm{Pr}>\mathrm{F}=<.0001 ; \mathrm{dh}=-0.45$} \\
\hline Ekspor minyak kelapa sawit Malaysia & XMYPO & & & & & \\
\hline Intercept & Inter & 0.5567 & 0.44 & 0.6642 & - & \\
\hline Nilai t & ERM & 0.1804 & 0.58 & 66 & - & \\
\hline Harga miny: & PPOWR & -0.0003 & -0.64 & 289 & - & \\
\hline Penamba & ADMY & -0.4069 & -2.98 & 0.0057 & -0.0161 & -0.4399 \\
\hline Lag XMYPO & LXMYPO & 0.9635 & 24.87 & 001 & - & \\
\hline \multicolumn{7}{|c|}{$\mathrm{R} 2=0.9789 ; \mathrm{F}$ hitung $=347.28 ; \mathrm{Pr}>\mathrm{F}=<.0001 ; \mathrm{dh}=-3.19$} \\
\hline Permintaan minyak kelapa & DID & & & & & \\
\hline & Intercept & 2.1908 & 1.95 & 03 & - & \\
\hline Har & $\mathrm{PPO}$ & -0.0009 & -2.13 & & -0.2888 & -0.3098 \\
\hline GL & GD & 0.0025 & 4.52 & 01 & 0.7905 & 0.8480 \\
\hline OWR & OWR & 0.0014 & 1.24 & 0.2260 & - &  \\
\hline Lag DID & LDID & 0.0678 & 0.34 & 0.7390 & - & \\
\hline \multicolumn{7}{|c|}{$\mathrm{R} 2=0.8450 ; \mathrm{F}$ hitung $=40.87 ; \mathrm{Pr}>\mathrm{F}=<.0001 ; \mathrm{dh}=-$} \\
\hline awit Malaysia & DMY & & & & & \\
\hline Inter & Intercept & 0.0940 & 0.13 & 0.8945 & - & \\
\hline Harg & PPOMYR & -0.0024 & -1.52 & & -0.3725 & -7.8838 \\
\hline Malaysia & PCO & 0.0017 & 1.87 & 0.0714 & 0.3691 & 7.8099 \\
\hline GDl & GDP & 0.0001 & 0.79 & & - & \\
\hline Lag DMY & LDMY & 0.9527 & 6.02 & 001 & - & \\
\hline \multicolumn{7}{|c|}{$\mathrm{R} 2=0.9235 ; \mathrm{F}$ hitung $=90.55 ; \mathrm{Pr}>\mathrm{F}=<.0001 ; \mathrm{dh}=-2.77$} \\
\hline apa sawit India & MINPO & & & & & \\
\hline Intercept & Intercept & 0.2324 & 0.43 & 0.6691 & - & \\
\hline Lag Pertum & LGERINRR & -0.0178 & -1.21 & 0.2370 & - & \\
\hline Harga minyak sawit dunia & PPOWR & -0.0002 & -0.52 & 0.6076 & - & \\
\hline GDP India & GDPIN & 0.0025 & 3.06 & 0.0046 & 0.5709 & 1.2693 \\
\hline
\end{tabular}




\begin{tabular}{|c|c|c|c|c|c|c|}
\hline \multirow{2}{*}{ Nama Peubah } & \multirow{2}{*}{ Notasi } & \multirow{2}{*}{$\begin{array}{l}\text { Parameter } \\
\text { Dugaan }\end{array}$} & \multirow{2}{*}{ t hitung } & \multirow{2}{*}{$\operatorname{Pr}>|\mathbf{t}|$} & \multicolumn{2}{|c|}{ Elastisitas } \\
\hline & & & & & $\mathbf{E}_{\mathrm{SR}}$ & $\mathbf{E}_{\mathrm{LR}}$ \\
\hline Lag MINPO & \multicolumn{5}{|c|}{$\mathrm{R} 2=0.9308 ;$ Fhitung $=100.86 ; \operatorname{Pr}>\mathrm{F}=<.0001 ; \mathrm{dh}=0.67$} & \\
\hline $\begin{array}{l}\text { Impor minyak kelapa sawit China } \\
\text { Intercept }\end{array}$ & \multicolumn{6}{|l|}{$\mathrm{MCHPO}$} \\
\hline Penambahan ERCHYR & AERCHYR & -0.0298 & -0.21 & 0.8356 & - & \\
\hline Lag2 PPOWR & L2PPOWR & -0.0003 & -1.71 & 0.0966 & -0.1335 & -1.8632 \\
\hline \multicolumn{7}{|c|}{$\mathrm{R} 2=0.9588 ; \mathrm{F}$ hitung $=240.59 ; \mathrm{Pr}>\mathrm{F}=\langle .0001 ; \mathrm{dh}=-0.14$} \\
\hline Impor minyak kelapa sawit Pakistan & MPAPO & & & & & \\
\hline Intercept & Intercept & 0.0359 & 0.31 & 0.7588 & - & \\
\hline Nilai tukar Rupee & ERPARR & -0.0010 & -0.60 & 0.5540 & - & \\
\hline Harga minyak sawit dunia & PPOWR & -0.0001 & -2.23 & 0.0335 & -0.1120 & -0.2795 \\
\hline GDP Pakistan & GDPPA & 0.0009 & 2.75 & 0.0100 & 0.5499 & 1.3730 \\
\hline Lag MPAPO & LMPAPO & 0.5995 & 4.70 & $<.0001$ & - & \\
\hline \multicolumn{7}{|c|}{$\mathrm{R} 2=0.9802 ; \mathrm{F}$ hitung $=371.18 ; \mathrm{Pr}>\mathrm{F}=<.0001 ; \mathrm{dh}=-0.43$} \\
\hline Harga minyak kelapa sawit Indonesia & PPOIDR & & & & & \\
\hline Inter & Intercept & -57.2872 & -0.24 & 0.8096 & - & \\
\hline Penan & ASID & -49.7498 & -0.66 & 129 & - & \\
\hline Penc & ADID & 32.3421 & 0.97 & 379 & ـ & \\
\hline Har & PPOWR & 0.4291 & 2.27 & 0.0306 & 0.2702 & 1.1561 \\
\hline Lag PPOIDR & LPPOIDR & 0.7663 & 8.01 & $<.0001$ & - & \\
\hline \multicolumn{7}{|c|}{$\mathrm{R} 2=0.8812 ; \mathrm{F}$ hitung $=55.65 ; \mathrm{Pr}>\mathrm{F}=<.0001 ; \mathrm{dh}=2.12$} \\
\hline Harga minyak kelapa sawit Malaysia & PPOMYR & & & & & \\
\hline Intercept & Intercept & -124.4210 & -2.06 & 0.0480 & - & \\
\hline Penambahan SMY & ASMY & -28.4630 & -2.13 & 0.0415 & -0.0319 & -0.0328 \\
\hline Lag2 DMY & L2DMY & 51.6898 & 7.27 & $<.0001$ & 0.2858 & 0.2944 \\
\hline Harga minyak sc & PPOWR & 0.6267 & 12.88 & $<.0001$ & 0.9009 & 0.9282 \\
\hline Lag PPOMYR & LPPOMYR & 0.0294 & 0.42 & 0.6806 & - & \\
\hline \multicolumn{7}{|c|}{$\mathrm{R} 2=0.9127 ; \mathrm{F}$ hitung $=78.41 ; \mathrm{Pr}>\mathrm{F}=<.0001 ; \mathrm{dh}=2.41$} \\
\hline yak kelapa sawit Dunia & $\overline{\mathrm{PPO}}$ & & & & & \\
\hline Inter & Inte & 127.4093 & 0.90 & & - & \\
\hline Penambahan & APSOWR & 0.6497 & 3.88 & 0.0006 & -0.0358 & -0.0783 \\
\hline Harga minyak biji bung & PSFWR & 0.3066 & 1.65 & 0.1091 & 0.3966 & 0.8664 \\
\hline Total ekspor minyak sawit & TXWPO & -33.5182 & -1.21 & 0.2366 & - & \\
\hline Total impor minyak sawit & TMWPO & 32.1758 & 1.17 & 0.2519 & - & \\
\hline Lag PPOWR & LPPOWR & 0.5422 & 3.27 & 0.0028 & - & \\
\hline \multicolumn{7}{|c|}{$\mathrm{R} 2=0.9393 ; \mathrm{F}$ hitung $=89.75 ; \mathrm{Pr}>\mathrm{F}=<.0001 ; \mathrm{dh}=6.00$} \\
\hline
\end{tabular}

Penawaran minyak kelapa sawit Malaysia dipengaruhi oleh tiga peubah yaitu lag harga minyak kelapa sawit Malaysia (LPPOMYR), lag luas lahan kelapa sawit Malaysia (LAHMY), dan lag penawaran minyak kelapa sawit Malaysia (LSMY). Dari tiga peubah yang dimasukkan kedalam persamaan penawaran minyak kelapa sawit Malaysia, hanya satu peubah yang berpengaruh secara signifikan, yaitu peubah lag luas lahan kelapa sawit Malaysia (LAHMY). Nilai parameter lag luas lahan kelapa sawit Malaysia sebesar 0,9628 dapat diartikan bahwa apabila lag luas lahan kelapa sawit Malaysia meningkat sebesar 1.000 hektar, maka penawaran minyak kelapa sawit Malaysia akan meningkat sebesar 962,8 ton. Peubah lag luas lahan kelapa sawit Malaysia (LAHMY) tidak responsif dalam jangka pendek, namun bersifat responsif dalam jangka panjang terhadap penawaran minyak kelapa sawit Malaysia. Nilai elastisitas jangka panjang $\left(\mathrm{E}_{\mathrm{LR}}\right)$ peubah lag luas lahan kelapa sawit Malaysia (LAHMY) adalah sebesar 1,3281 dapat diartikan bahwa apabila lag luas lahan kelapa sawit Malaysia meningkat sebesar 10 persen, maka penawaran minyak kelapa sawit Malaysia akan meningkat sebesar 13,281 persen.

Ekspor minyak kelapa sawit Indonesia dipengaruhi oleh tiga peubah, yaitu nilai tukar Rupiah terhadap US Dolar (ERIDRR), penambahan harga minyak kelapa sawit dunia (APPOWR) , dan lag ekspor minyak kelapa sawit Indonesia (LXIDPO). Dari ketiga peubahpeubah yang dimasukkan kedalam model persamaan, hanya peubah nilai tukar Rupiah terhadap US Dolar (ERIDRR) yang berpengaruh signifikan. Nilai parameter nilai tukar Rupiah terhadap US Dolar (ERIDRR) adalah sebesar 0,0005 dapat diartikan bahwa apabila nilai Rupiah meningkat (Rupiah terdepresiasi) sebesar Rp. 1.000,00 maka ekspor minyak kelapa sawit Indonesia akan meningkat sebesar 
0,5 juta ton. Berdasarkan nilai elastisitas diketahui bahwa dalam jangka panjang perubahan nilai tukar Rupiah terhadap US Dolar bersifat responsif terhadap ekspor minyak kelapa sawit Indonesia. Nilai $E_{L R}$ nilai tukar Rupiah terhadap US Dolar adalah 1,1503 dapat diartikan jika Rupiah terdepesiasi sebesar 10 persen, maka dalam jangka panjang akan menyebabkan ekspor minyak kelapa sawit Indonesia akan meningkat sebesar 11,503 persen. Hasil penelitian ini sejalan dengan penelitian yang dilaksanakan oleh Hardy (2015) yang menyatakan bahwa harga mempunyai hubungan yang positif tetapi tidak signifikan terhadap harga ekspor. Penelitian tersebut juga menyatakan bahwa nilai tukar mempunyai pengaruh positif dan signifikan terhadap ekspor CPO Indonesia. Harga minyak kelapa sawit dunia (CPO) mempunyai pengaruh negatif dan signifikan terhadap ekspor CPO Indonesia.

Ekspor minyak kelapa sawit Malaysia dipengaruhi oleh empat peubah yaitu nilai tukar Ringgit terhadap US Dolar (ERMYRR), harga minyak kelapa sawit dunia (PPOWR), penambahan permintaan minyak kelapa sawit Malaysia (ADMY) dan lag ekspor minyak kelapa sawit Malaysia (LXMYPO). Peubah penambahan minyak kelapa sawit Malaysia (ADMY) berpengaruh signifikan terhadap ekspor minyak kelapa sawit Malaysia. Meskipun demikian, perubahan peubah penambahan permintaan minyak kelapa sawit domestik (ADMY) tidak berpengaruh besar atau bersifat tidak responsif dalam jangka pendek maupun jangka panjang. Hasil penelitian ini tidak sejalan dengan penelitian yang dilaksanakan oleh Yusoff (1998), yang menyimpulkan bahwa harga berpengaruh secara signifikan terhadap ekspor minyak kelapa sawit di Sabah, Malaysia.

\section{Permintaan Minyak Kelapa Sawit}

Blok permintaan minyak kelapa sawit terdiri dari lima persamaan, yaitu permintaan minyak kelapa sawit Indonesia (DID), permintaan minyak kelapa sawit Malaysia (DMY), impor minyak kelapa sawit India (MINPO), impor minyak kelapa sawit China (MCHPO), dan impor minyak kelapa sawit Pakistan (MPAPO). Secara umum, peubahpeubah yang bersifat responsif dalam jangka panjang adalah harga minyak kelapa sawit Malaysia (PPOMYR), harga minyak kelapa Malaysia (PCOMYR), GDP India per kapita (GDPIN), lag 2 tahun harga minyak kelapa sawit Malaysia (L2PPOWR) dan GDP Pakistan per kapita (GDPPA).

Permintaan minyak kelapa sawit Indonesia dipengaruhi oleh harga minyak kelapa sawit Indonesia (PPOIDR), GDP Indonesia per kapita (GDPID), penambahan harga minyak kedelai dunia (APSOWR), dan lag permintaan minyak kelapa sawit Indonesia (LDID). Peubahpeubah yang berpengaruh signifikan terhadap permintaan domestik minyak kelapa sawit Indonesia adalah harga minyak kelapa sawit Indonesia (PPOIDR) dan GDP Indonesia per kapita (GDPID). Berdasarkan hasil analisis dapat dinyatakan bahwa baik dalam jangka pendek maupun dalam jangka panjang kedua peubah tersebut bersifat tidak responsif atau tidak elastis terhadap permintaan minyak kelapa sawit Indonesia.

Permintaan minyak kelapa sawit Malaysia dipengaruhi oleh harga minyak kelapa sawit Malaysia (PPOMYR), harga minyak kelapa Malaysia (PCOMYR), GDP Malaysia per kapita (GDPMY) dan lag permintaan minyak kelapa sawit Malaysia (LDMY). Peubah-peubah yang berpengaruh signifikan terhadap permintaan minyak kelapa sawit Malaysia adalah harga minyak kelapa sawit Malaysia (PPOMYR) dan harga minyak kelapa Malaysia (PCOMYR). Dalam jangka panjang kedua peubah tersebut bersifat responsif terhadap permintaan minyak kelapa sawit Malaysia. Dalam jangka panjang, peningkatan harga minyak kelapa sawit Malaysia (PPOMYR) sebesar 10 persen akan menyebabkan permintaan minyak kelapa sawit Malaysia menurun sebesar 78,38 persen. Sementara itu peningkatan harga minyak kelapa Malaysia (PCOMY) sebesar 10 persen akan menyebabkan permintaan minyak kelapa sawit Malaysia meningkat sebesar 78,099 persen.

Impor minyak kelapa sawit India dipengaruhi oleh lag pertumbuhan nilai tukar Rupee India terhadap US Dolar (LGERINRR), harga minyak kelapa sawit dunia (PPOWR), GDP India per kapita (GDPIN), dan lag impor minyak kelapa sawit India (LMINPO). Dari keempat peubah yang dimasukkan kedalam persamaan, hanya peubah GDP per kapita India (GDPIN) yang berpengaruh signifikan. Peubah GDP per kapita India (GDPIN) bersifat responsif dalam jangka panjang. Nilai $E_{L R}$ peubah GDP India per kapita (GDPIN) adalah 1,2693 dapat diartikan bahwa jika pendapatan per kapita masyarakat India (GDPIN) meningkat sebesar 10 persen, maka impor minyak kelapa 
sawit India akan meningkat sebesar 12,693 persen.

Impor minyak kelapa sawit China dipengaruhi oleh tiga peubah, yaitu penambahan nilai tukar Renminbi China terhadap US Dolar (AERCHYR), lag 2 tahun harga minyak kelapa saiwt dunia (L2PPOWR), dan lag impor minyak kelapa sawit China tahun sebelumnya (LMCHPO). Peubah yang berpengaruh signifikan terhadap impor minyak kelapa sawit China adalah lag 2 tahun harga minyak kelapa sawit dunia. Dilihat dari nilai elastisitas jangka pendek peubah tersebut tidak berpengaruh signifikan terhadap impor minyak kelapa sawit China, sedangkan dalam jangka panjang perubahan peubah lag 2 tahun harga minyak kelapa sawit dunia bersifat elastis. Nilai elastisitas jangka panjang $\mathrm{E}_{\mathrm{LR}}$ peubah lag 2 tahun harga minyak kelapa sawit dunia adalah sebesar -1,8632 dapat diartikan bahwa jika lag 2 tahun harga minyak kelapa sawit dunia (L2PPOWR) meningkat sebesar 10 persen, makan impor minyak kelapa sawit China akan menurun sebesar 18,632 persen.

Impor minyak kelapa sawit Pakistan dipengaruhi oleh empat peubah, yaitu nilai tukar Rupee India terhadap US Dolar (ERPARR), harga minyak kelapa sawit Pakistan, GDP Pakistan per kapita (GDPPA), dan lag impor minyak kelapa sawit Pakistan (LMPAPO). Dari keempat peubah yang dimasukkan kedalam model, terdapat dua peubah yang berpengaruh secara signifikan yaitu peubah harga minyak kelapa sawit dunia (PPOWR) dan GDP Pakistan per kapita (GDPPA). Namun jika dilihat dari nilai elastisitasnya, hanya peubah GDP Pakistan per kapita (GDPPA) yang bersifat responsif dalam jangka panjang. Elastisitas jangka panjang peubah GDP Pakistan per kapita adalah sebesar 1,3730 dapat diartikan bahwa jika pendapatan per kapita penduduk Pakistan (GDPPA) meningkat sebesar 10 persen maka impor minyak kelapa sawit Pakistan akan meningkat sebesar 13,730 persen.

\section{Harga Minyak Kelapa Sawit}

Blok harga minyak kelapa sawit terdiri dari tiga persamaan yaitu harga minyak kelapa sawit Indonesia (PPOID), harga minyak kelapa sawit Malaysia (PPOMY), dan harga minyak kelapa sawit dunia (PPOW). Secara umum peubah-peubah yang berpengaruh signifikan adalah harga minyak kelapa sawit dunia (PPOWR), penambahan penawaran minyak kelapa sawit Malaysia (ASMY), lag 2 tahun permintaan domestik minyak kelapa sawit Malaysia (L2DMY), penambahan harga minyak kedelai dunia (APSOWR), dan harga minyak biji bunga matahari (PSFWR).

Harga minyak kelapa sawit Indonesia dipengaruhi oleh penambahan penawaran minyak kelapa sawit Indonesia (ASID), penambahan permintaan domestik minyak kelapa sawit Indonesia (ADID), harga minyak kelapa sawit dunia (PPOWR) dan lag harga minyak kelapa sawit Indonesia (LPPOIDR). Dari empat peubah yang dimasukkan kedalam persamaan, terdapat satu peubah yang bersifat responsif dalam jangka panjang, yaitu harga minyak kelapa sawit dunia (PPOWR). Berdasarkan perhitungan nilai elastisitas, dapat dikatakan bahwa dalam jangka panjang peningkatan harga minyak kelapa sawit dunia (PPOWR) sebesar 10 persen akan menyebabkan harga minyak kelapa sawit Indonesia meningkat sebesar 11,561 persen. Hasil analisis ini sejalan dengan penelitian yang dilakukan oleh Hardy (2015) bahwa produksi CPO mempunyai pengaruh negatif terhadap harga namun pengaruhnya tidak signifikan. Hasil penelitian tersebut juga menunjukkan bahwa harga minyak kelapa sawit dunia berpengaruh signifikan terhadap harga minyak kelapa sawit Indonesia.

Harga minyak kelapa sawit Malaysia dipengaruhi oleh empat peubah, yaitu penambahan penawaran minyak kelapa sawit Malaysia (ASMY), lag 2 tahun permintaan minyak kelapa sawit Malaysia (L2DMMY), harga minyak kelapa sawit dunia (PPOWR), dan lag harga minyak kelapa sawit Malaysia (LPPOMYR). Peubah yang berpengaruh signifikan terhadap harga minyak kelapa sawit Malaysia adalah peubah penambahan penawaran minyak kelapa sawit Malaysia (ASMY), lag 2 tahun permintaan domestik minyak kelapa sawit Malaysia (L2DMY), dan harga minyak kelapa sawit dunia (PPOWR). Hasil analisis menunjukkan bahwa kedua peubah tersebut tidak responsif dalam jangka pendek maupun dalam jangka panjang.

Harga minyak kelapa sawit dunia dipengaruhi secara signifikan oleh peubah penambahan harga minyak kedelai dunia (PSOWR) dan harga minyak biji bunga matahari dunia (PSFWR). Dapat disumpulkan juga bahwa kedua peubah tersebut tidak responsif dalam jangka pendek maupun dalam jangka panjang. 


\section{KESIMPULAN}

Beberapa kesimpulan yang dapat diambil berdasarkan hasil analisis pada penelitian ini adalah: (1) Pada blok penawaran, faktor-faktor dominan yang mempengaruhi penawaran minyak kelapa sawit adalah lag luas areal kelapa sawit Indonesia (LAHID), harga pupuk urea (PURIDR), lag luas areal kelapa sawit Malaysia (LAHMY), nilai tukar Rupiah terhadap US Dolar (ERIDRR), dan penambahan permintaan domestik minyak kelapa sawit Malaysia (ADMY); (2) Pada blok permintaan, faktorfaktor dominan yang mempengaruhi permintaan minyak kelapa sawit adalah GDP per kapita India (GDPIN), lag 2 tahun harga minyak kelapa sawit dunia (L2PPOWR), harga minyak kelapa sawit dunia (PPOWR), dan GDP per kapita Pakistan (GDPPA); (3) pada blok harga, faktor-faktor dominan yang mempengaruhi harga minyak kelapa sawit adalah harga minyak kelapa sawit dunia (PPOWR), penambahan penawaran minyak kelapa sawit Malaysia (ASMY), lag 2 tahun permintaan domestik minyak kelapa sawit Malaysia (L2DMY), penambahan harga minyak kedelai dunia (APSOWR), dan harga minyak biji bunga matahari (PSFWR); (3) Dalam jangka pendek, tidak terdapat peubah yang bersifat responsif terhadap penawaran dan permintaan minyak kelapa sawit; (4) Dalam jangka panjang, peubah yang bersifat responsif terhadap penawaran dan permintaan minyak kelapa sawit Indonesia adalah lag luas areal kelapa sawit Indonesia (LAHID), lag luas kelapa sawit Malaysia (LAHMY), nilai tukar Rupiah terhadap US Dolar (ERIDRR), harga minyak kelapa sawit Malaysia (PPOMYR), harga minyak kelapa Malaysia (PCOMYR), GDP per kapita India (GDPIN), lag 2 tahun harga minyak kelapa sawit dunia (L2PPOWR), GDP per kapita Pakistan (GDPPA), dan harga minyak kelapa sawit dunia (PPOWR).

\section{UCAPAN TERIMA KASIH}

Terimakasih diucapkan kepada Universitas Riau yang telah mendanai penelitian ini melalui Lembaga Penelitian dan Pengabdian kepada Masyarakat (LPPM) Universitas Riau, yaitu Dana DIPA Universitas Riau tahun anggaran 2019.

\section{DAFTAR PUSTAKA}

Bank Indonesia. 2018. Laporan Perekonomian Indonesia Tahun 2017. Bank Indonesia, Jakarta.

BPDP. 2019. Sawit Komoditas Strategis Indonesia. https://www.bpdp.or.id/id/ info-grafis/en-sawit-komoditas-strate gisindonesia/. Diakses Tanggal 17 November 2019.

FAO. 2019. www.faostat.fao.org . Diakses Tanggal 05 November 2019.

Gujarati, D. 2011. Dasar-Dasar Ekonometrika. Salemba Empat, Jakarta.

Hardy, Jhon. 2015. Analisis Determinan Ekspor Crude Palm Oil (CPO) Indonesia ke Uni Eropa. INTEGRITAS 1(4): 100-110.

Heriyanto, H., Karya, D., Choanji, T., Asrol, A., Bakce, D. and Elinur, E., 2019.

Regression Model in Transitional Geological Environment For Calculation Farming and Production of Oil Palm Dominant Factor in Indragiri Hilir Riau Province. Journal of Geoscience, Engineering, Environment, and Technology, 4(1), pp.5665.

Intriligator, M.D. 1978. Econometrics Model, Techniques, and Applications. Prentice Hall Inc, New Jersey.

Koutsoyiannis, A. 1977. Theory of Econometrics. McGraw-Hill Publish-ing Co, New York.

Pindyck, R. S. dan D. L. Rubinfeild. 1998. Econometric Models and Economic Forecasts. Fourth Edition. Mc Garw-Hill Inc, New York.

Sekretariat Direktorat Jenderal Perkebunan. 2018. Statistik Perkebunan Indonesia 2017 - 2019. http://ditjenbun. pertanian.go.id. Diakses Tanggal 19 September 2019.

Sipayung, Tungkot dan Purba, Jan Horas. 2015. Ekonomi Agribisnis Minyak Sawit. PASPI, Bogor.

Sukirno, S. 2014. Makroekonomi Teori Pengantar. PT Raja Grafindo Persada, Jakarta.

Yusoff, Remali. 1998. An Econometric Analysis of the Supply and Demand for Palm Oil in Sabah. Jurnal Kinabalu IV : 136-159. 